\title{
CONSCIOUSNESS TO LIBERATE: In Search of the Political Paradigm of Muhammadiyah
}

\author{
Ridho Al-Hamdi \\ Universitas Muhammadiyah Yogyakarta \\ Jl. Brawijaya, Kasihan, Bantul, Yogyakarta, Indonesia, 55183 \\ e-mail: ridhoalhamdi@umy.ac.id
}

\begin{abstract}
This paper examines the political paradigm of Muhammadiyah in thinking and behaving because Muhammadiyah can survive to surpass political impediments for more than a century ago. Methodologically, it is qualitative research by utilising documentary study and in-depth interviews as the data-gathering technique. The finding demonstrates that "consciousness to liberate" is the political paradigm of Muhammadiyah. This paradigm has three interrelated dimensions: transcendental dimension, humanistic dimension, and modernity dimension. The former indicates the prophetic consciousness, the middle demonstrates the liberation theology, and the latter denotes the values Muhammadiyah's goal. Therefore, the Muhammadiyah consciousness to strives for prophetic missions not merely restricted to liberate humankind from colonisation, oppression, backwardness, and poverty but also to liberate mustadh'afin from unfair policies and liberal systems.
\end{abstract}

Keywords: Muhammadiyah, consciousness, political paradigm, liberation, al-Mâ'ûn 


\section{Introduction}

The dynamics between Muhammadiyah and politics commenced since its establishment in 1912 when Ahmad Dahlan as the founder of Muhammadiyah needed to learn on how to organise an association with Boedi Oetomo, one of the acknowledged nationalist movements in Indonesia at the time. Thus, Muhammadiyah historically was born amongst political situations when Indonesia was under the Dutch occupation. In the following development, Muhammadiyah always addresses political impediments when it behaves various activities, whether in the field of education, health, social, or $d a^{w} w a$ (Islamic proselytising). Under the colonisation period, Muhammadiyah should deal with the Dutch and Japan governments to maintain its survival through mutual and strategic cooperation. In this period, Muhammadiyah has had a problematic relationship with Sarekat Islam. When Indonesia was in the situation against the Dutch colonisation under the Physical Revolution (1945-1949), a lot of Muhammadiyah resources like humans, building, and other physical facilities were destroyed.

During Soekarno's regime, the political channel of Muhammadiyah can be seen in the Masyumi behaviour despite many critiques to the relation both. When the tragedy of "Gestapu" (the 30 September Movement) took place in 1965, the role of Muhammadiyah transformed not merely as Ormas (the religious force) but also as Ormaspol (the religious and political forces) in dealing with such a situation. It was reinforced by Indonesia's Deputy Prime Minister of Social and Political Affairs Adam Malik which stated that Muhammadiyah was considered to take its position as a political party and has rights to take part in the government institutions both at national and regional levels. ${ }^{1}$ The role as Ormaspol operated by Muhammadiyah merely for a few years because there was an initiation among Muhammadiyah elites to create a new political party. ${ }^{2}$ After a long term and challenging 
process, the new party, namely the Indonesian Muslim Party (Parmusi), was established on 20 February 1968. Although Muhammadiyah cadres dominated the functionaries of Parmusi, the internal conflict took place where the government intervened the party until the application of the party fusion by the New Order regime in 1971.

Since 1971 until the present, Muhammadiyah has been declaring itself as the interest group and the moral force by employing the strategies of the elite lobby and influencing policymakers. Although Muhammadiyah has no organisational relation with and not affiliated with any political forces, the political aspirations of Muhammadiyah members and devotees remain to be channelled into various political parties. Although Muhammadiyah cadres and members ever established and maintained some political parties like the National Mandate Party (PAN) and the National Sun Party (PMB), the political aspiration of Muhammadiyah members were not merely restricted to such parties but also spreading into all parties. Even currently Muhammadiyah members can take part as the Tim Sukses (success team) in winning its candidates whether in executive or legislative election.

The political journey of Muhammadiyah for more than a century ago is not a brief history. This time is a rigorous formation in searching for its political paradigm, which should be analysed in a theoretical framework. This paper is an effort to find out the political paradigm of Muhammadiyah. Global societies will recognise Muhammadiyah as the most influential Islamic modernistreformist movement in Indonesia. Even it goes to enlarge its networks around the globe. Therefore, it is fascinating to be examined further the political paradigm of Muhammadiyah.

Studying the dynamics of Muhammadiyah and politics has been conducted by the following scholars. Noer explains the development of Islamic modernist movements in Indonesia, 
including Muhammadiyah from 1900 to 1942 in responding to the Dutch colonisation. More specifically, Alfian scrutinises the political behaviour of Muhammadiyah under the Dutch colonisation of 1990-1942. Meanwhile, Shihab investigates the response of Muhammadiyah to the penetration of Christianity in Indonesia. Under Indonesia's Soekarno regime, Hamka and Syaifullah depict the political engagement of Muhammadiyah inside the Consultative Council of Indonesian Muslim Associations (Masyumi Party). Although Madinier focuses on revealing the political dynamics inside Masyumi, he still includes the critical role of Muhammadiyah cadres in that party. Likewise, Noer also portrays the involvement of Muhammadiyah activists in the Indonesian political landscape of 1945-1965. ${ }^{3}$

Afterwards, Nashir's (2000) finding shows the accommodative behaviour of Muhammadiyah in dealing with the government during the New Order regime with, mainly the case in Pekalongan Regency, Central Java Province. Meanwhile, Jurdi (2010) investigates the dynamics of Muhammadiyah in coping with Indonesian changeable political issues from 1966 to 2006. In the different analysis, Syaifullah (2019b) succeeds to uncover that there is no different achievement quantitatively for Muhammadiyah in reaching the parliamentary seats throughout, whether the structural strategy (having a political party) or the cultural strategy (having not a political party). ${ }^{4}$

Many pieces of research on the dynamics of Muhammadiyah and politics was conducted in Indonesia's post-New Order regime of 1998. Asyari (2008) theorises that the politics of Muhammadiyah in a decade after-1998 is focusing on realising the political ijtihad of Amin Rais through the establishment of PAN and, in turn, the relation between them is politically well-built. Al-Hamdi (2013) and Efendi (2014) reveals that the politics of Muhammadiyah elites have spawned in a continuum from the moderate-inclusive 
stance to a fundamentalist-exclusive one. Whilst Al-Hamdi (2013) focuses on differentiating the political attitude of Muhammadiyah elites in coping with three issues (the desire to realise of the Jakarta Charter, the emergence of Islam-based political parties, and the debatable discourse of jihad and terrorism), Efendi (2014) intends to discover the political fragmentation of Muhammadiyah elites into various attitudes in addressing the 2009 presidential election.

Although Muhammadiyah is not a political party or a political movement, it has a significant role in influencing public opinions related to political issues. ${ }^{5}$ Afterward, Jung (2014) argues that Muhammadiyah can manage to refrain from supporting a particular political party at the organisational level. ${ }^{6}$ Nevertheless, Al-Barbasy (2018) postulates that the position of Muhammadiyah in keeping a same close and a same distance with any political forces is a dilemma choice. ${ }^{7}$ During Susilo Bambang Yudhoyono's administration between 2004 and 2014, Muhammadiyah reveals a critical position to government policies, mainly related to natural resources and gas and oil laws. It is part of the constitutional jihad which is always promoted by Muhammadiyah. ${ }^{8}$ In the meantime, under Jokowi's administration, Muhammadiyah has a harmonious relation. It is part of the flexibility of Muhammadiyah in promoting a high politics. That's why Kasman Bakry et.al demonstrate that Muhammadiyah has a comprehensive concept on a state which is operated through cultural and political strategies in the context of a moral politics. ${ }^{9}$ In responding to the issue of the desire to adopt the Jakarta Charter in the 1945 Constitution in post-New Order regime, there are three models of political thoughts in Muhammadiyah elites, namely the moderatetransformative, the moderate-realistic, and the accommodativepragmatic. It denotes to the fact that none of the elites in Muhammadiyah encourages the concept of the Islamic state. ${ }^{10}$ 
Furthermore, Wardana and Hidayat (2019) argue that although Muhammadiyah already declared that itself is in the neutral position to any political moments, their finding proves the multiplicity of Muhammadiyah's political engagement by taking the case of the 2019 Regional Representative Council (DPD) election in Yogyakarta, West Sumatera, and South Sulawesi. In addition to that, Nashir, Qodir, Nurmandi, Jubba, and Hidayati $(2019,1-24)$ portray the success of Muhammadiyah in taking a moderate way with any political forces in the 2019 presidential election so that Muhammadiyah is not trapped into the politics of partisan. ${ }^{11}$

Earlier works indicate one thing that the examination on the dynamics of Muhammadiyah and politics in an intellectual debate is an irresistible inquiry for anyone. Although Muhammadiyah has been declaring that it never changes itself as a political party since its establishment, it always relates itself with such low politics. Although Muhammadiyah commits to be a socioreligious movement to disseminate the teachings of the Prophet Muhammad PBUH, politics is one of the crucial strategies to expand Muhammadiyah $d a$ 'wa to society.

Differentiated with previous works, it is significant for this paper to discover a scientific truth, namely the political paradigm of Muhammadiyah as an initial proposal which being a normal science on how to think and behave conducted by socio-religious organisations like Muhammadiyah in coping with changeable political issues which restricted by time and space. Due to an initial proposal, it is open to be criticised by other scholars if this proposal does not fulfil the requirement to solve the existing puzzles in political anomalies. That is a science; scientific truth is not absolute truth. This is the novelty of the paper is the concept of "consciousness to liberate" as the 
political paradigm of Muhammadiyah in thinking and behaving in addressing any political circumstances.

\section{A Theoretical Framework}

The term "paradigm" is being fundamental when Thomas S. Kuhn, American philosopher, wrote a book entitled "The Structure of Scientific Revolution" in 1962. According to Kuhn (1962), science is a system of knowledge covering general truths of the operation of general laws, mainly as obtained and tested through scientific methods. That is what Kuhn (1962) puts forward as "paradigm shift" consisting of a fourfold gradual and cycling phase, commenced from (1) normal science, then it moves to (2) anomalies, and (3) crisis which needs (4) revolution. The upshot of these four phases is a new normal science which replaces the previous normal science. It is like a spinning wheel; it never ends and is dynamic. Science is not a doctrine, so that it always continues to change and respond to any realities restricted by time and space. ${ }^{12}$

Normal science can be understood as research firmly based upon one or more past scientific achievements. Some scholarly communities, in turn, recognise such achievements for a time as supplying the foundation for its further actions. It can be cocalled as a "paradigm". A group of practitioners (and their students) study this paradigm to become members of the particular scientific community in which they will later practice. How is a paradigm created? It begins from an inquiry conducted by scientists towards the same phenomena, describes and interprets them in different ways. From the competition of these preparadigmatic schools, one paradigm appears and to be approved as the best paradigm than others. Such a paradigm is adhered by scientific groups, written in specialised journals, having professional 
institutions, and achieving a special place in academe. Kuhn (1962) mentions normal science like solving a puzzle because puzzles generally have predetermined solutions. ${ }^{13}$

Due to restricted by time and space, one day, a paradigm addresses anomaly. It is caused by the fact that the paradigm cannot solve the changeable phenomena. Thus, the paradigm shift is evitability. How does paradigm change come about? There are two ways: through discovery resulting in the novelty of fact or by invention resulting in the newness of theory. Discovery commences with the awareness of anomaly violated the previous paradigm, which governs normal science. The paradigm shift is complete when the previous paradigm has been adjusted with the anomalous.

The awareness of anomaly is part of an invention. The appearance of a new theory is generated by the persistent failure of the puzzles of normal science to be solved as they should. Failure of existing rules is the prelude to a search for new ones. Paradigm is, in turn, blurred. This is an initial sign of crisis because the paradigm cannot solve anomaly and put it in a normal situation. Thus, alternative paradigms are needed to be invented. A new paradigm is wanted. When a new paradigm can solve anomaly, such paradigm is fought for. Crises eventually provide a chance to retool the existing paradigm.

A scientific revolution which results in a paradigm shift is analogous to a political revolution. Revolution can be understood as a radical change in the way of thinking in illustrating something. The competition among paradigms will result in a paradigm which is different from the past paradigm in addressing the following anomaly. During the scientific revolution, scholars see new and different things when looking with familiar instruments in place they have looked before. In a sense, after a revolution, 
scholars respond to a different world. Why does a shift in view occur? Indeed, it is because of genius in depicting and interpreting phenomena. These are four steps in a paradigm shift which affecting a scientific revolution in science.

\section{Methodology}

In undertaking this research, a qualitative-based method is employed in seeking various studies on the dynamics of Muhammadiyah and politics. ${ }^{14}$ Among five kinds of qualitative research, namely narrative, phenomenological, grounded theory, ethnographic, and case study, this paper prefers to adopt the case study approach due to its relevance. ${ }^{15}$ Thus, this paper selects Muhammadiyah as a case study because it represents the most influential Islamic reformist movement in Indonesia.

Documentary study and in-depth interview were employed as data-gathering techniques (Patton 2002). The documentary study was carried out before, during, and after the field research. Supporting documents coming from Muhammadiyah and appropriate scholarly references will be utilised also in this research. For the in-depth interview, it was conducted with three relevant informants: Ahmad Syafii Maarif (former general chairperson of Muhammadiyah 1998-2005), Abdul Munir Mulkhan (former secretary of Muhammadiyah 2000-2005), and Syukriyanto AR (one of the chairpersons of Muhammadiyah 2010-2015). The given data were analysed in a fourfold step: reducing data, displaying data, verification, and concluding remarks. ${ }^{16}$

\section{Results and Discussion}

This study proposes a normal science, namely "consciousness to liberate" as the political paradigm of Muhammadiyah in 
thinking and behaving when Muhammadiyah addresses political anomalies. This paradigm primarily is constructed based on three interrelated dimensions: prophetic consciousness, the spirit of liberation, and progressive Islam values as depicted in Picture 1. The former denotes a transcendental dimension, the middle demonstrates a humanistic dimension, while the latter indicates a religious-based modernity dimension.

\section{Prophetic Consciousness: The Unity of Self and Ilahiah Consciousness}

Islam has been teaching its devotees with "innamal a 'malu binniyat" (the deeds depend on the intention) indicating that all kinds of actions conducted by humans in this life truly depends on the intention. The intention is recognised merely by human as the subject and God because the intention is consciousness to will and located inside the human's mind and soul. When someone intends to do something, no one knows until he/she demonstrates his/her intention to others. Otherwise, others will know an intention from manifested deeds behaved by the human. The intention is a manifestation of self-consciousness in reaching hidden desires inside the human's mind and soul, delivered through oral, and realised via actions. In Islam, selfconsciousness emerges from inside of the human, not from outside. According to Kuntowijoyo (2001), Islam moves from inside to outside, not from outside to inside. When someone intends to do something, it means that he/she has self-consciousness to realise it. $\mathrm{He} / \mathrm{she}$ will be more confident when he/she behaves something based on the truth he/she believes. ${ }^{17}$

In Islam, there is an acknowledged statement related to self-consciousness, namely "man 'arafa nafsahu faqad 'arafa rabbahu" (Whosoever recognises himself knows his Lord). It denotes the fact that it is not possible to recognise our God if we do not 
really know and understand ourselves as a human wholly. In other words, self-consciousness on who we are is the right path to recognise the nature of Ilahiah (Godness). The pure selfconsciousness will bring into the consciousness of the Creator. Consequently, self-consciousness principally affects the vital understanding of the concept of multidimensional human. Someone who has self-consciousness as a multifaceted human will reflect the nature of him/herself in this life that he/she lives not merely in an ideal situation but also real life. Therefore, when self-consciousness copes with any external conflicts or clashes outside the human, it will be built stronger.

In dealing with various conflicts, human tends to use his/ her analytical framework or worldview, which, in turn, being the foundation of a particular ideology adhered by a person and groups to define who they are, their identity and community. ${ }^{18}$ The difference in ideology is caused by the difference in forming the framework of the world. Syariati (2001) argues that worldview is an understanding of the existence of realities. It can be seen with the presence of Confucianism, Hegel's dialectics, Marx's materialism-dialectics, Nietzsche's nihilism, and Heidegger's existentialism which denote to so-called as "worldview". Each worldview will discuss human as a major concept. ${ }^{19}$

Therefore, the worldview transforms and creates an ideology as the belief obeyed a person and a community. According to Sargent (2009), ideology is a system of values and beliefs concerning the various institutions and processes of society which are acknowledged as the truth by a group of people. Ideology will provide a depiction of the world both as it is and as it should be, and it organises the tremendous complexity of the world into something fairly simple and understandable. ${ }^{20}$ Likewise, Ball, Dagger, and O’Neill (2014) stress the concept of ideology as a set of ideas which performs four functions for people: explaining and evaluating 
social conditions, helping people understand their place in society and providing a programme for social and political actions. Ideology attempts to link up thoughts (ideas and beliefs) to action, to shape how people think and, in turn, how they act. Each ideology provides a vision of the social and political world to inspire people to act either to change or to preserve their way of life. ${ }^{21}$

Furthermore, Syari'ati (2001) postulates that ideology is the most valuable nature and the most special consciousness inside the human. Ideological consciousness was born from a reflective process and constructed by a human who can interpret social conditions. In brief, ideology has a role in building selfconsciousness, perspective and understanding as well as to direct human deeds in the interaction with others. ${ }^{22}$ If Syari'ati believes that ideology is the principal framer of consciousness, Kuntowijoyo argues that ideology is merely one of the parts which make such consciousness. According to Kuntowijoyo (2001), there are three kinds of worldview adopted by Indonesian people, mainly Muslim communities to understand the dynamics of social life, i.e. mythological worldview, ideological worldview, and scientific worldview. These three worldviews influence self and collective consciousness in Muslim history. ${ }^{23}$

Moreover, Kuntowijoyo (2001) proposes the prophetic spirit as a foundation to build human consciousness, namely consciousness as part of the best humankind having a responsibility to continue the prophetic mission of the Prophet Muhammad PBUH. Kuntowijoyo (2001) depicts three interrelated elements on the formation of prophetic consciousness: ta'muruna bil ma'rûf (humanisation), tanhawna 'anil munkar(liberation), and tu'minuna billâh (transcendency). The Kuntowijoyo's concept is based on Al-Qur'an Chapter 3 verse 110, the meaning: "(Believers), you are the best community singled out for people: you order what is right, forbid what is 
wrong, and believe in God". The concept of amar ma'rûf (you order what is right) can be understood not merely behaving good deeds but also emancipating human in order to be Iqbal's insan kamil (perfect human being). The fulfilment of nahi munkar (forbid what is wrong) can begin from prohibiting bad ones into liberating human from any oppression, dehumanisation, colonisation, poverty, backwardness, and the like. Meanwhile, the realisation of tu'minuna billâh (believe in God) is begging everything merely to God. It is so-called as tauhîid (unification of oneness of God). ${ }^{24}$

According to Rahman (2011), prophetic consciousness is a faith call to act social changes among society. This call comes from Allah, which not merely restricted to the responsibility of His Messengers but also should be continued by all humans until the present. In the context of axiology, the prophetic consciousness aims to elevate human dignity and to fight for social justice as was done by His Messengers. This consciousness is a moral movement towards the enlightenment of mankind. Thus, transcendental consciousness (tauhîld-based consciousness) is not merely restricted by individual dimensions but also having broad social dimensions. The Messengers are the right example who can interpret the individual piety into the social piety. It denotes the fact that the personal piety should implicate into human kindness. ${ }^{25}$

In Indonesia, Amin Rais is one of the Muslim scholars who disseminate so-called "social tauhît" to society. Rais (1991) hypothesises that "social tauhîl" is a social dimension of the tauhîd so that society can integrate and realise their faith in good practices among social life. Thus, tauhîid should be transformed into the form of high ethics. The implication is the emergence of tauhîl-based human who can think and act wisely. In the social-political context, the ethics should be realised not only 
in the individual interaction but also in public space. ${ }^{26}$ In Muhammadiyah, Ahmad Dahlan is a good instance which has an ideal self-consciousness. He can integrate textual values (AlQur'an and As-Sunnah teachings) and social situations (social traditions and problems). Dahlan's genius to integrate both generates self-consciousness to create an Islamic renewal movement in Indonesia.

\section{AI-Mâ'ǘn and Liberation Theology}

Theology is an epistemological foundation to think and behave, particularly in religious affairs. Thus, spiritual piety cannot be separated from religious theology. Assmann (1975) defines theology as a critical reflection of the historical process of liberation..$^{27}$ In the meantime, Gustavo (1988) conceptualises theology as a crucial reflection affecting the construction of an in-depth view, understanding, and thought towards religious issues. ${ }^{28}$ In the context of the liberation theology, Löwy (1988) stresses that this concept proposes to transform religious values into humanitarian missions, namely against to resist a social gap and injustice. Thus, Löwy (1988) introduces three principal doctrines of liberation theology. First, this theology is a robust resistance towards capitalism as an exploitative, injustice, and uncivilised system. Second, this theology is the right choice for poor people theology on behalf of their struggle in insisting on freedom and justice. Third, this theology is a critique of an old theology as part of the product of Greek philosophy. ${ }^{29}$

In Islam, the notion of liberation theology is introduced by Asghar Ali Engineer through his book entitled Islam and Liberation Theology. He proposes not merely the transcendental theology but also the theology which reflects real human experiences. It means that religion is the actual practice of human liberation and, in turn, to uphold human dignity. ${ }^{30}$ Engineer (1990) strongly 
believes that Islam has the source of values, teachings, and history, which could be developed to be a liberation theology. Nevertheless, he argues that the inability of Islam being a liberation theology because of a robust dogma dominated by sufism and metaphysical values for centuries ago. This dogma cannot interact with empirical facts in society, overlooks people interests, and closes to elite and power. It does not merely make Muslims are oppressed by the power but also stutter to cope with modernity. ${ }^{31}$

Therefore, Engineer (1999) argues on the need to formulate an Islamic liberation theology with four essential features. First, it is a critical reflection based on present realities. Second, it never legitimates elite groups who are oppressing poor people. Third, it is being an inspiration of oppressed people to think and behave in addressing any suppression and injustice. Fourth, it recognises that the human has a free will and free choice to decide their life. Afterwards, Engineer (1999) suggest to Muslims doing these following steps to create such theology. First, Muslims should re-examine the prophetic spirit (humanisation, liberation, transcendency) that Islam needs to stand for mustadh 'arifin (poor people) and remove any oppression. Second, Muslims must learn revolutionary theologies in Islamic history, such as Qaramitah's anti-elitism, Ikhwanul Muslimin under Hassan Al-Banna, Iranian Shi' ite in the upcoming revolution, etc. Third, Muslims need to re-interpret al-Qur'an verses because many cases of interpretation abuse to the verses were conducted by Muslim scholars merely for power interests. ${ }^{32}$

In the history of Indonesian Islam, the spirit of liberation theology appears along with the establishment of a religious renewal movement in 1912, namely Muhammadiyah. This movement was born to respond to Muslims and Indonesian society problems at the time, such as religious stagnation, backwardness, poverty, and colonisation. Ahmad Dahlan succeeded to perform not 
merely in reforming religious outlooks but also proposing transformativebased religious exegesis. He can respond to and solve public impediments with various enlightening agenda through his new interpretations. He taught Al-Qur'an not merely for recitation but also should be practised (the unification of mind and actions). Thus, one of the thoughts affecting the establishment and development of Muhammadiyah is al-Mâ'ûn theology, based on Al-Qur'an Chapter 107 with seven verses.

The spirit of al-Mấûn theology, in turn, is interpreted into three main pillars of Muhammadiyah services: schooling, healing, and feeding. ${ }^{33}$ This kind of spirit eventually makes Muhammadiyah having hundreds of colleges, schools, hospitals, orphanages, philanthropic institutions, and other social welfare services. Noer (1973) and Jainuri (2002) argues that Muhammadiyah has been succeeding to liberate mustadh afin (the oppressed) from any oppressions. ${ }^{34}$ Therefore, al-Mâtûn is being a foundation of Ahmad Dahlan in developing Muhammadiyah as a liberation movement from any backwardness, stupidity, and poverty and as an enlightening movement to advance science and technology. ${ }^{35}$ Some scholars argue that Dahlan's interpretation of Chapter alMấûn is a primary source of Islamic liberation theology in Indonesia.

Dahlan's al-Mấûn movement with a welas-asih (compassion) approach is the fundamental value of the prophetic spirit. It is a power influencing people to advocate peers. The al-Mấun theology is also part of the sustainable struggle of prophetic values done by His Messengers. ${ }^{36}$ In the interview with Munir Mulkhan (2020), he labels al-Mấûn theology as the "humanist theology", where human gets into the paradise is not enough only with shalat (praying) and shaum (fasting) but also with a consciousness of caring among creatures, a consciousness of caring towards poverty, and a consciousness of caring towards 
any injustices. In brief, the liberation theology is a humanistic spirit which is contained powerfully in Chapter al-Mâ'ûn.

In the following developments, although the al-Mấun theology has various interpretations, there is an agreed meaning that it is the spirit having the alignments towards poor, marginalised, and oppressed people culturally and structurally. Huda (2011) demonstrates four phases of the development of such theology. First phase is the interpretation introduced by Ahmad Dahlan where Muhammadiyah is a liberation movement liberating humankind from any colonisation, poverty, and backwardness throughout tangible services: schooling, healing, and feeding. Second phase is the emergence of the notion "social tauhîd" introduced by Amin Rais in the Muhammadiyah Congress of 1995. ${ }^{37}$ Such tauhîd could be implemented in the context of the enforcement of social justice in political life as Rais behaved when he succeeded in couping Soeharto's New Order regime. ${ }^{38}$ Haedar Nashir argues that "social tauhîid" is remaining the continuation of al-Mấun theology. In the interview with Ahmad Syafii Maarif (2019), when Muhammadiyah under his leadership from 1998 to 2005, "social tauhîld" can bee seen with the emergence of the anti-corruption movement along with Nahdhatul Ulama (NU). In this second phase, al-Mấûn theology is directed not only to solve social problems but also national obstructions.

Third phase is the interpretation conducted by the Network of Muhammadiyah Young Intellectuals (JIMM) in 2003 that the al-Mấun theology is a liberation effort of so-called "new mustadh 'afin". This term denotes poor society not merely oppressed and marginalised by economic affairs but also social, cultural, and political issues under the neo-liberal era. The emergence of this notion is affected by the fact that "social tauhî corruption movement" are not useful to solve national obstacles. Therefore, Abdurrahman (2010) proposes the idea of "transformative 
theology" despite criticised by Kuntowijoyo. ${ }^{39}$ Instead, Kuntowijoyo (2001) offers the "prophetic social science" where science can be another alternative for a theology.$^{40}$ Fourth phase is establishing legal institutions focusing on advocating poor and marginalised society as part of the realisation of the al-Mấûn theology such as the Council of Community Empowerment(MPM), Muhammadiyah Institute of Amil Zakat Infaq Shadaqah (Lazismu), and Muhammadiyah Disaster Management Center (MDMC). It began since the Muhammadiyah Congress of 2005 in Malang. Thohari (2017) catalogues those three institutions as "Muhammadiyah New Trident" being part of the continuation of "Muhammadiyah Old Trident". If the former focuses on empowering, philanthropy, and disaster, the latter consists of schooling, healing, and feeding. ${ }^{41}$

In contemporary national life, Muhammadiyah still contextualises the al-Mấun spirit into political issues through the notion "Jihad of Constitution" introduced by Din Syamsuddin in 2009. It is also part of amar ma'rûf nahi munkar (doing good deeds and abandoning bad ones) to resist unfair regulations. Hence, this notion underlines the importance of the state is still in line with the constitutional goals so that it can perform for social welfare, economic justice, and national savvy. Through "Jihad of Constitution", Muhammadiyah intended to revise all acts and regulations which are contradicted with the 1945 Constitution, mainly Article 33 on Economic Sovereignty. Muhammadiyah put forward that $U U$ Migas (Act of Oil and Gas) removed the state role in governing the oil and natural gas resources for people welfare and justice. It means that $U U$ Migas has been contradicted with the 1945 Constitution Article 33, where the state should govern the strategic resources. The upshot, the "Jihad of Constitution" succeeded to change some acts and regulations. One of them was the Act of Water Resource. 
Al-Mấûn is a theological and historical consciousness inherited by Ahmad Dahlan for Muhammadiyah. It is a strong foundation of Muhammadiyah to continue prophetic missions, i.e. amar ma'rûf nahi munkar. The principal value of Mấûn as the Islamic liberation theology is fighting for and advocating poor and marginalised people. "Jihad of Constitution" is a contemporary interpretation and embodiment of the Mấûn theology. This theology is also reinforced by hadith of the Prophet Muhammad PBUH, namely “innama tunsarun bi du' afaikum" (Indeed that you will be helped due to feeble people among of you).

\section{The Values of Islam Berkemajuan}

The source of the notion "Islam Berkemajuan" (loosely, Islam with progress) can be traced back into Al-Qur'an Chapter Saba' (34) verse 15, namely "baldatun thoyyibatun wa robbun ghafur" (a beautiful and prosperous land whose people have been forgiven by Allah). In other words, this verse indicates a safe, justice, and prosperous state, including blessed by Allah. In the context of Muhammadiyah, this verse, in turn, translated as "Masyarakat Islam yang sebenar-benarnya" (the ideal Islamic society, MIYS). In the meantime, MIYS can be understood as "Islam Berkemajuan". This concept, for the first time, is introduced by Ahmad Dahlan to his disciplines in order to be progressive humans, i.e. human who always adheres Islamic teachings and in line with current situations. It means that Islam should be shaleh li kulli zamân wa al-makân (contextual whenever and wherever).

Tim Penyusun PP Muhammadiyah (2015) defines the concept "Berkemajuan" as an ideal process and goal, the ultimate goodness, and, in turn, it leads all aspects of life, whether a material civilisation (lahiriyyah) or a non-material civilisation (ruhaniyyah). It indicates continuity as the manifestation of an effort to earn 
a sustainable development goal. ${ }^{42}$ Likewise, Ali (2015) conceptualises "Islam Berkemajuan" as an Islamic understanding and practice deemed moderate, progressive, enlightened, and democratic. ${ }^{43}$ According to PP Muhammadiyah (2015), Islam principally is dîn al-hadlarah (a progressive religion) to manifest the enlightened human life and the progressive civilisation. Therefore, "Islam Berkemajuan" is an outcome of the prophetic consciousness' values (humanisation-liberation-transcendency). Ideologically speaking, it is a transformation form of al-Mấ $\hat{u} n$ theology to present $d a^{6} w a$ in real life of society. ${ }^{44}$ In other words, it is a combination of text and context.

Based on the concept "Islam Berkemajuan", Muhammadiyah has a strong commitment to fight for values of rightness, goodness, peace, justice, advantages, and wealth towards a civilised society. Islam was born to uphold human dignity without any discrimination. It proclaims anti-war, anti-terrorism, anti-violence, anti-oppression, anti-backwardness, and anti-all kinds of damaging earth like corruption, abuse of power, crimes against humanity, and natural exploitation. It protects pluralism practices on behalf of ethnics, races, nations, groups, and cultures. It disseminates values of peace, tolerance, and moderate-progressive attitudes in all aspects of life so that it can create a civilised society nationally and globally. Hence, Islam is rahmatan lil 'âlamîn (a blessing for the whole universe) in enlightening "ke-Indonesia-an" (Indonesianness) and the global world. ${ }^{45}$

The role of Muhammadiyah through its cadres in realising "Islam Berkemajuan" can also be seen after Indonesian Independence of 1945. Mas Mansur and Soekarno stressed the importance of progressive and moderate attitudes so that Muslims will advance if they can think logically and permeate the substance of Islamic values. Ki Bagus Hadikusumo put forward the concept of a nation of "maju dan berkemajuan" (advanced and progressive) 
when he involved in the sessions of the 1945 Constitution discussion organised the Committee for Preparatory Work for Indonesian Independence (BPUPKI) and the Preparatory Committee for Indonesian Independence (PPKI). ${ }^{46}$ Muhammadiyah in the following developments is still consistent in practising the values of "Islam Berkemajuan" through Muhammadiyah trident activities, whether "Muhammadiyah Old Trident" or "Muhammadiyah New Trident".

With "Islam Berkemajuan" in political life, Muhammadiyah has been attempting to integrate Islamic values and Indonesian cultures. Muhammadiyah will always advance national growth and prioritise the moral of political Islam among ideological clashes of the word. ${ }^{47}$ The government acknowledgement to various Muhammadiyah cadres as the national heroes (such as Ahmad Dahlan, Siti Walidah, Fachrodin, Mas Mansur, Ki Bagus Hadikusumo, Kasman Singodimedjo, Abdul Kahar Muzakkir, Soedirman, etc.) is a tangible proof that Muhammadiyah already contributed to the advancement of Indonesia.

The notion "Islam Berkemajuan" indeed cannot be separated from the concept "Indonesia Berkemajuan" (Indonesia with progressive). It was born in the land of Indonesia to contribute its advancement. Therefore, the concept of "Indonesia Berkemajuan" has three main features. First is progressive in thinking and behaving as well as future-oriented. Second is progressive in realising a better situation in both material and spiritual life. Third is progressive to be an excellence in all aspects of experience in the context of the cooperation with other nations. Thus, "Indonesia Berkemajuan" is an inevitability to realise the governance of a free, fair, prosperous, peaceful, humane, dignified, and sovereign nation. ${ }^{48}$

The concept of a progressive state basically can be traced back into the notion "al-Madînah al-Fadhîlah" (an ideal state) 
introduced by al-Fârâbî (872-950 C), a Muslim philosopher originated from Kazakhstan. Al-Fârâbî’s idea indicates a prosperous and civilised country which based on science and technology. Thus, Tim Penyusun PP Muhammadiyah (2015) defines that the progressive state is a state promoting the implementation of the prophetic mission, supported by excellent human resources and the noble moral. It should establish the sovereignty of territory, politics, laws, economics, and culture. It can realise prosperity, i.e. the fulfilment of basic human needs. It can fulfil material and spiritual happiness. It guarantees freedom of thinking, freedom of expression, and religious freedom. It respects human rights. It also creates security and a future guarantee. ${ }^{49}$

In the political perspective, a progressive state is a democratic state which imbued by wisdom and deliberation/representation, based on a fair law, and upholding civilised values. Wisdom should be based on the plural life of the nation. Meanwhile, the deliberation or representation can be manifested into state institutions as the channel of political aspirations fairly to all people. Thus, the progressive state should be based on the values of belief in God, humanity, unity, deliberation, and justice. The ethics in realising democracy can be shown in the practices of prioritising honesty, peace, noble, and respect as well as against violence, fraudulence, and Machiavellian strategies. ${ }^{50}$

In the economic context, a progressive state can be seen with the fulfilment of economic system based on science and technology with the values of sovereignty, justice, sustainability, and the utilisation of land, sea, and air potencies. In implementing a growing economy, the state should (1) provide decent jobs and livelihood for citizens, (2) fulfil basic human needs, (3) guarantee citizens' rights to earn an education and increase the human resource quality, (4) provide safety to poor society through social security networks, (5) regulates an economic system which 
governs the role of state and private sectors in line with the 1945 Constitution where the country should master the national resources for people welfare, (6) realise the national economy based on the values of togetherness, efficiency, justice, sustainability, environment friendly, and independent as well as maintain the balance of the advancement and unity of the national economy. ${ }^{51}$

Considering the notion "Islam Berkemajuan", Muhammadiyah strongly expects to create Indonesia as a Pancasila state with progressive by applying ten Muhammadiyah characteristics. First is doing good deeds and fighting for peace and prosperity. Second is enlarging friends and practising Islamic brotherhood. Third is having patience and a broad view by remaining to uphold Islamic teachings. Fourth is religious and social. Fifth is following all legal regulations and state philosophy. Sixth is amar ma'rûf nahi munkar in all aspects of life and being a good example. Seventh is activating in a community development based on Islamic teachings. Eighth is doing cooperation with any Muslim communities as well as promoting, practising, and standing for Islamic teachings. Ninth is assisting the government and cooperating with other communities in the framework of maintaining and building the state in earning a fair and prosperous society, including blessed by God. Tenth is fair and collective inward and forward wisely. ${ }^{52}$ If all principles of the progressive state can be realised in a constitutional manner, a peaceful life can be achieved by all citizens who dwell inside the state.

\section{Conclusion}

Uncovering the political paradigm of Muhammadiyah can be earned. It consists of three interrelated dimensions. First is the prophetic consciousness as the unity of self and ilahiah consciousness. Second is al-Mấûn as the representation of Islamic 
liberation theology. Third is the values of "Islam Berkemajuan" as the manifestation of the verse "baldatun thoyyibatun wa robbun ghafur" and Muhammadiyah's goal of MIYS. The former denotes the transcendental dimension, the middle indicates the humanistic dimension, and the latter demonstrates the modernity dimension. These three dimensions can be so-called as "consciousness to liberate". It is not a sufism-based paradigm, which far away from real-life. It is not a secular paradigm, which avoids the belief in God. It is not also a paradigm, which depends merely on technological intelligence where it indeed removes human values.

The "consciousness to liberate" is a prophetic consciousness paradigm to liberate humankind from any oppression. It also to liberate mustadh áfin from colonisation, discrimination, backwardness, stupidity, and poverty. To some extent, it aims to release people from unfair laws, policies, and regulations. Even it liberates society from liberal systems in all aspects of life. To fulfil this paradigm, courageous and strategic steps should be designed to purify and reform the state constitution and other political systems. Therefore, "consciousness to liberate" is a balancing paradigm among others and not trapped in any extreme paradigms. This paradigm will be a guideline for Muhammadiyah members and devotees on how to think and behave consistently in coping with not restricted merely to political issues. The upshot, Muhammadiyah's goal of the ideal Islamic society can be fulfiled entirely. All in all, the concept of "consciousness to liberate" as the political paradigm of Muhammadiyah is the novelty of this paper. Meanwhile, the limitation of this study is inability to examine the relation of Muhammadiyah with the practical politics whether at national or local level. 


\section{Acknowledgement}

The author expresses sincere gratitude to the Council of Higher Education, Research, and Development (Diktilitbang) Central Board of Muhammadiyah in providing the generous grant for this research under the contract number of 0984.012/ I.3/D/2019. Our honest thanks also goes to all informants who spent their time and shared their fruitful experiences to improve this paper.

\section{References}

Abdurrahman, Moslem. "Dakwah Pemberdayaan." Suara Muhammadiyah, Special Volume Muktamar Satu Abad 13 (2010).

Al-Ansi, Abdullah M., Ishomuddin, Tri Sulistyaningsih, and Rinikso Kartono. "Rational Choice of Following Muhammadiyah and Nahdlatul Ulama and Their Social and Political Role in Indonesian Society.” Open Access Library Journal 6 (2019).

Al-Barbasy, Ma'mun Murod. "Muhammadiyah Dan Politik: Dilema Antara Keep Close Dan Keep Distance.” Kontekstualita: Jurnal Penelitian Sosial dan Keagamaan 34 (2017).

Al-Hamdi, Ridho. "Islam and Politics: Political Attitudes of the Elites in Muhammadiyah 1998-2010.” Indonesian Journal of Islam and Muslim Societies 3, no. 2 (2013).

—. "The Jakarta Charter in Post-Soeharto Indonesia: Political Thoughts of the Elites in Muhammadiyah." Masyarakat Indonesia 41, no. 01 (2015).

— . "The Origin of the Political Consciousness in Muhammadiyah: An Epistemological Analysis toward Indonesia's MuslimReformist Organization.” Indonesian Journal of Islamic Literature and Muslim Society 5, no. 2 (2020). 
Alfian. Muhammadiyah the Political Behavior of a Muslim Modernist Organization under Dutch Colonialism. Yogyakarta: Gadjah Mada University Press, 1989.

Ali, Muhammad. "The Muhammadiyah's 47th Congress and Islam Berkemajuan.” Studia Islamika 22, no. 2 (2015).

Amaladoss, M. "Life in Freedom: Liberation Theologies from Asia.” Maryknoll: Orbis Books, 1997.

Assmann, H. Practical Theology of Liberation. London: Search Press, 1975.

Asyari, Suaidi. "Ijtihâd-Based Politics: The Muhammadiyah Political Participation in Post-Soeharto.” Studia Islamika 15, no. 1 (2008).

Bakry, Kasman, Ambo Asse, Darussalam Syamsuddin, Kasjim Salenda, and Roziana Shaari. "Political Dynamics of Muhammadiyah and Its Relevance to the Concept of the State in Islam." Al-'Adalah 17, no. 2 (2020).

Ball, T., R. Dagger, and D. O'Neill. Political Ideologies and the Democratic Ideal. Boston: Pearson Education Inc, 2014.

Berg, B. L., and H. Lune. Qualitative Research Methods for Social Sciences. Boston and New York: Pearson Education, 2012.

Burhani, Ahmad Najib. "Makna Teologi Al-Ma'un Di Dua Generasi Muhammadiyah." Suara Muhammadiyah, no. 13, 2013.

Creswell, John W. Qualitative Inquiry and Research Design: Choosing Among Five Approaches. Third Edition. Thousand Oaks: Sage Publications, 2013.

Denzin, Norman K., and Yvonna S. Lincoln. Introduction: The Discipline and Practice of Qualitative Research. In Denzin, Thousand Oaks, United States: Sage, 2011.

Efendi, David. Politik Elite Muhammadiyah: Studi Tentang Fragmentasi Elite Muhammadiyah. Yogyakarta: Reviva Cendikia, 2014. 
Engineer, Asghar Ali. Islam and Liberation Theology: Essays on Liberative Elements in Islam. New Delhi: Sterling Publishers, 1990.

Flyvbjerg, Bent. Case Study. N. K. Denz. Thousand Oaks: Sage, 2011.

Gustavo, G. A Theology of Liberation: History, Politics, and Salvation. 15th ed. Maryknoll: Orbis Books, 1988.

Hamka. Muhammadiyah-Masyumi. Jakarta: Masyarakat Islam, 1956.

Huda, S. “Teologi Mustad'afin Di Indonesia: Kajian Atas Teologi Muhammadiyah.” Tsaqafah 7, no. 2 (2011).

Jainuri, Achmad. "The Formation of the Muhammadiyah's Ideology 1912-1942.” In PhD Dissertation. McGill University: US America, 1999.

Jung, Eunsook. "Islamic Organizations and Electoral Politics in Indonesia: The Case of Muhammadiyah.” South East Asia Research 22, no. 1 (2014).

Jurdi, Syarifuddin. Muhammadiyah Dalam Dinamika Politik Indonesia 1966-2006. Yogyakarta: Pustaka Pelajar, 2010.

Kuhn, Thomas S. The Structure of Scientific Revolutions. Chicago and London: The University of Chicago Press, 1962.

Kuntowijoyo. Muslim Tanpa Masjid. Bandung: Mizan, 2001.

Löwy, M. Marxisme et Théologie de La Libération. Amsterdam: IIRE, 1988.

Madinier, Remy. Partai Masjumi: Antara Godaan Demokrasi Dan Islam Integral. Jakarta: Mizan, 2013.

Miles, M. B., and A. M. Huberman. Qualitative Data Analysis: An Expanded Sourcebook. Thousand Oaks: Sage, 1994.

Mulkhan, Abdul Munir. Jejak Pembaruan Sosial Dan Kemanusiaan Kiai Ahmad Dahlan. Jakarta: PT Kompas Media Nusantara, 2010. 
Muthahhari, Murthadha. Mengenal Epistemologi: Sebuah Pembuktian Terhadap Rapuhnya Pemikiran Asing Dan Kokohnya Pemikiran Islam. Jakarta: Lentera, 2001.

Nashir, Haedar. Perilaku Politik Elit Muhammadiyah. Yogyakarta: Tarawang, 2000.

Nashir, Haedar, Zuly Qodir, Achmad Nurmandi, Hasse Jubba, and Mega Hidayati. "Muhammadiyah's Moderation Stance in the 2019 General Election: Critical Views from Within." Al-Jamiah: Journal of Islamic Studies 57, no. 1 (2019): 124.

Noer, Deliar. Partai Islam Di Pentas Nasional: Kisah Dan Analisis Perkembangan Politik Indonesia 1945-1965. Jakarta: LP3ES, 2000.

__. "The Modernist Muslim Movement." PhD Diss., McGill University, 1999.

- The Modernist Muslim Movement in Indonesia 19001942: East Asian Historical Monographs. Oxford: Oxford University Press, 1973.

PP Muhammadiyah. "Laporan PP Muhammadiyah Periode 19651968 Kepada Muktamar Muhammadiyah Ke-37 Pada Tanggal 21-26 September 1968 Di Yogyakarta.” In Unpublished Document, p.4, 1968.

—. "Negara Pancasila Sebagai Darul Ahdi Wasy Syahadah." Yogyakarta: PP Muhammadiyah, 2015.

Rahman, Fazlur. Prophecy in Islam: Philosophy and Orthodoxy. Chicago: University of Chicago Press, 2011.

Rais, Mohammad Amin. Cakrawala Islam: Antara Cita Dan Fakta. Bandung: Mizan, 1991.

Sardiman. "Masyarakat Madani, Muhammadiyah, Dan Politik." Informasi 28, no. 1 (2000).

Sargent, L. T. "Contemporary Political Ideologies: A Comparative Analysis.” Belmont: Cengage Learning, 2009.

Shihab, Alwi. Membendung Arus: Respon Gerakan Muhammadiyah 
Terhadap Penetrasi Misi Kristen Di Indonesia. Yogyakarta: Suara Muhammadiyah, 2016.

Suara Muhammadiyah. "Laporan PP Muhammadiyah: Dari Mu'tamar Ke Tanwir Masalah Organisasi Dan Politik (Bagian II Habis).” In Suara Muhammadiyah, 1966.

—_. "Situasi Tanah Air: Pilih Presiden Baru." Suara Muhammadiyah, no. 10 (1966).

Syaifullah. Gerak Politik Muhammadiyah Dalam Masyumi. Yogyakarta: Suara Muhammadiyah, 2019.

—. Pergeseran Politik Muhammadiyah. Yogyakarta: Suara Muhammadiyah, 2019.

Syari’ati, Ali. "Man and Islam.” Translated by Ghulam M. Fayez. Masyhad: University of Masyhad Press, Jahad Publications, 1982.

Thohari, Hajriyanto Y. "Muhammadiyah Sebagai Gerakan Filantropi: Perspektif Historis Dan Sosiologis." In The Unpublished Documen Was Presented on "Kajian Raadhan" Organized by PWM East Jawa, 03-04 June 2017. Jawa Timur: Universitas Muhammadiyah Malang, 2017.

Tim Penyusun PP Muhammadiyah. "Indonesia Berkemajuan: Rekonstruksi Kehidupan Berbangsa Yang Bermakna." Yogyakarta: PP Muhammadiyah, 2015.

Tohari, Sjafri Sairin, Muhammad Azhar, and M. Nurul Yamin. "Muhammadiyah's Criticism Towards Government Policies in The Era of Din Syamsudin's Leadership." Al Albab 9, no. 1 (2020).

Wardana, Amika, and Syahrul Hidayat. "The Multiplicity of Muhammadiyah's Political Engagement in Indonesia's DPD Election.” Studia Islamika 26, no. 1 (2019). 


\section{Endnotes:}

${ }^{1}$ PP Muhammadiyah, "Laporan PP Muhammadiyah Periode 1965-1968 Kepada Muktamar Muhammadiyah Ke-37 Pada Tanggal 21-26 September 1968 Di Yogyakarta," in Unpublished Document, 1968, 4; Suara Muhammadiyah, "Situasi Tanah Air: Pilih Presiden Baru," Suara Muhammadiyah, no. 10, 1966, 26.

2 PP Muhammadiyah, "Laporan PP Muhammadiyah Periode 1965-1968 Kepada Muktamar Muhammadiyah Ke-37 Pada Tanggal 21-26 September 1968 Di Yogyakarta”; Suara Muhammadiyah, "Situasi Tanah Air: Pilih Presiden Baru," Suara Muhammadiyah, No. 10, 1966, 15; Suara Muhammadiyah, "Laporan PP Muhammadiyah: Dari Mu'tamar Ke Tanwir Masalah Organisasi Dan Politik (Bagian II Habis),” Suara Muhammadiyah, 1966, 26.

${ }^{3}$ Deliar Noer, The Modernist Muslim Movement in Indonesia 1900-1942: East Asian Historical Monographs (Oxford: Oxford University Press, 1973); Alfian, Muhammadiyah the Political Behavior of a Muslim Modernist Organization under Dutch Colonialism (Yogyakarta: Gadjah Mada University Press, 1989); Alwi Shihab, Membendung Arus: Respon Gerakan Muhammadiyah Terhadap Penetrasi Misi Kristen Di Indonesia (Yogyakarta: Suara Muhammadiyah, 2016); Hamka, MuhammadiyahMasyumi (Jakarta: Masyarakat Islam, 1956); Syaifullah, Gerak Politik Muhammadiyah Dalam Masyumi (Yogyakarta: Suara Muhammadiyah, 2019); Remy Madinier, Partai Masjumi: Antara Godaan Demokrasi Dan Islam Integral (Jakarta: Mizan, 2013); Deliar Noer, Partai Islam Di Pentas Nasional: Kisah Dan Analisis Perkembangan Politik Indonesia 1945-1965 (Jakarta: LP3ES, 2000).

${ }^{4}$ Haedar Nashir, Perilaku Politik Elit Muhammadiyah (Yogyakarta: Tarawang, 2000); Syarifuddin Jurdi, Muhammadiyah Dalam Dinamika Politik Indonesia 19662006 (Yogyakarta: Pustaka Pelajar, 2010); Syaifullah, Pergeseran Politik Muhammadiyah (Yogyakarta: Suara Muhammadiyah, 2019).

${ }^{5}$ Abdullah M. Al-Ansi et al., "Rational Choice of Following Muhammadiyah and Nahdlatul Ulama and Their Social and Political Role in Indonesian Society," Open Access Library Journal 6 (2019); Sardiman, "Masyarakat Madani, Muhammadiyah, Dan Politik," Informasi 28, no. 1 (2000).

${ }^{6}$ Eunsook Jung, "Islamic Organizations and Electoral Politics in Indonesia: The Case of Muhammadiyah,” South East Asia Research 22, no. 1 (2014).

${ }^{7}$ Ma'mun Murod Al-Barbasy, "Muhammadiyah Dan Politik: Dilema Antara Keep Close Dan Keep Distance,” Kontekstualita: Jurnal Penelitian Sosial dan Keagamaan 34 (2017).

${ }^{8}$ Tohari et al., "Muhammadiyah's Criticism Towards Government Policies in The Era of Din Syamsudin's Leadership," Al Albab 9, no. 1 (2020).

${ }^{9}$ Kasman Bakry et al., "Political Dynamics of Muhammadiyah and Its Relevance to the Concept of the State in Islam," Al-'Adalah 17, no. 2 (2020).

${ }^{10}$ Ridho Al-Hamdi, "The Jakarta Charter in Post-Soeharto Indonesia: Political Thoughts of the Elites in Muhammadiyah,” Masyarakat Indonesia 41, no. 01 (2015). 
${ }^{11}$ Suaidi Asyari, "Ijtihâd-Based Politics: The Muhammadiyah Political Participation in Post-Soeharto," Studia Islamika 15, no. 1 (2008); Ridho Al-Hamdi, "Islam and Politics: Political Attitudes of the Elites in Muhammadiyah 1998-2010," Indonesian Journal of Islam and Muslim Societies 3, no. 2 (2013); David Efendi, Politik Elite Muhammadiyah: Studi Tentang Fragmentasi Elite Muhammadiyah (Yogyakarta: Reviva Cendikia, 2014); Amika Wardana and Syahrul Hidayat, "The Multiplicity of Muhammadiyah's Political Engagement in Indonesia's DPD Election,” Studia Islamika 26, no. 1 (2019); Haedar Nashir et al., "Muhammadiyah's Moderation Stance in the 2019 General Election: Critical Views from Within," Al-Jami'ah: Journal of Islamic Studies 57, no. 1 (2019): 1-24.

12 Thomas S. Kuhn, The Structure of Scientific Revolutions (Chicago and London: The University of Chicago Press, 1962).

${ }^{13}$ Kuhn, The Structure of Scientific Revolutions.

${ }^{14}$ Norman K. Denzin and Yvonna S. Lincoln, Introduction: The Discipline and Practice of Qualitative Research, In Denzin (Thousand Oaks, United States: Sage, 2011).

${ }^{15}$ B. L. Berg and H. Lune, Qualitative Research Methods for Social Sciences (Boston and New York: Pearson Education, 2012); John W. Creswell, Qualitative Inquiry and Research Design: Choosing Among Five Approaches, Third Edit. (Thousand Oaks: Sage Publications, 2013); Bent Flyvbjerg, Case Study, N. K. Denz. (Thousand Oaks: Sage, 2011).

${ }^{16}$ Creswell, Qualitative Inquiry and Research Design: Choosing Among Five Approaches, M. B. Miles and A. M. Huberman, Qualitative Data Analysis: An Expanded Sourcebook (Thousand Oaks: Sage, 1994).

${ }^{17}$ Kuntowijoyo, Muslim Tanpa Masjid (Bandung: Mizan, 2001).

${ }^{18}$ Murthadha Muthahhari, Mengenal Epistemologi: Sebuah Pembuktian Terhadap Rapuhnya Pemikiran Asing Dan Kokohnya Pemikiran Islam (Jakarta: Lentera, 2001).

${ }^{19}$ Ali Syari’ati, "Man and Islam," in Trans. Ghulam M. Fayez (Masyhad: University of Masyhad Press, Jahad Publications, 1982).

${ }^{20}$ L. T. Sargent, "Contemporary Political Ideologies: A Comparative Analysis" (Belmont: Cengage Learning, 2009), p.2.

${ }^{21}$ T. Ball, R. Dagger, and D. O’Neill, "Political Ideologies and the Democratic Ideal” (Boston: Pearson Education Inc, 2014), p. 2.

${ }^{22}$ Syari'ati, "Man and Islam."

${ }^{23}$ Kuntowijoyo, Muslim Tanpa Masjid.

${ }^{24}$ Kuntowijoyo, Muslim Tanpa Masjid.

${ }^{25}$ Fazlur Rahman, Prophecy in Islam: Philosophy and Orthodoxy (Chicago: University of Chicago Press, 2011).

${ }^{26}$ Mohammad Amin Rais, Cakrawala Islam: Antara Cita Dan Fakta (Bandung: Mizan, 1991). 
${ }^{27}$ H. Assmann, Practical Theology of Liberation (London: Search Press, 1975).

${ }^{28}$ G. Gustavo, A Theology of Liberation: History, Politics, and Salvation, 15th ed. (Maryknoll: Orbis Books, 1988).

${ }^{29}$ M. Löwy, Marxisme et Théologie de La Libération (Amsterdam: IIRE, 1988).

${ }^{30} \mathrm{M}$. Amaladoss, "Life in Freedom: Liberation Theologies from Asia" (Maryknoll: Orbis Books, 1997), p. 131.

${ }^{31}$ Asghar Ali Engineer, Islam and Liberation Theology: Essays on Liberative Elements in Islam (New Delhi: Sterling Publishers, 1990).

${ }^{32}$ Engineer, Islam and Liberation Theology.

${ }^{33}$ Ahmad Najib Burhani, "Makna Teologi Al-Ma'un Di Dua Generasi Muhammadiyah," Suara Muhammadiyah, no. 13, 2013.

${ }^{34}$ Deliar Noer, "The Modernist Muslim Movement" (PhD diss., McGill University, 1999); Achmad Jainuri, "The Formation of the Muhammadiyah's Ideology 19121942” (PhD diss., McGill University, 1999).

${ }^{35}$ Ridho Al-Hamdi, "The Origin of the Political Consciousness in Muhammadiyah: An Epistemological Analysis toward Indonesia's Muslim-Reformist Organization," Indonesian Journal of Islamic Literature and Muslim Society 5, no. 2 (2020).

${ }^{36}$ Abdul Munir Mulkhan, Jejak Pembaruan Sosial Dan Kemanusiaan Kiai Ahmad Dahlan (Jakarta: Kompas Media Nusantara, 2010).

${ }^{37}$ S. Huda, "Teologi Mustad'afin Di Indonesia: Kajian Atas Teologi Muhammadiyah," Tsaqafah 7, no. 2 (2011).

${ }^{38}$ Rais, Cakrawala Islam: Antara Cita Dan Fakta.

${ }^{39}$ Moslem Abdurrahman, "Dakwah Pemberdayaan,” Suara Muhammadiyah, Special Volume Muktamar Satu Abad 13 (2010).

${ }^{40}$ Kuntowijoyo, Muslim Tanpa Masjid.

${ }^{41}$ Hajriyanto Y. Thohari, "Muhammadiyah Sebagai Gerakan Filantropi: Perspektif Historis Dan Sosiologis," The Unpublished Documen Was Presented on "Kajian Raadhan" Organized by PWM East Jawa, 03-04 June 2017 (Jawa Timur: Universitas Muhammadiyah Malang, 2017).

${ }^{42}$ Tim PenyusunPP Muhammadiyah, "Indonesia Berkemajuan: Rekonstruksi Kehidupan Berbangsa Yang Bermakna” (Yogyakarta: PP Muhammadiyah, 2015), 10.

${ }^{43}$ Muhammad Ali, "The Muhammadiyah's 47th Congress and Islam Berkemajuan," Studia Islamika 22, no. 2 (2015), 378.

${ }^{44}$ PP Muhammadiyah, "Negara Pancasila Sebagai Darul Ahdi Wasy Syahadah" (Yogyakarta: PP Muhammadiyah, 2015), 8.

${ }^{45}$ PP Muhammadiyah, "Negara Pancasila," 8-9.

${ }^{46}$ Tim Penyusun PP Muhammadiyah, "Indonesia Berkemajuan: Rekonstruksi Kehidupan Berbangsa Yang Bermakna” (Yogyakarta: PP Muhammadiyah, 2015), 13.

${ }^{47}$ PP Muhammadiyah, "Negara Pancasila Sebagai Darul Ahdi Wasy Syahadah” (Yogyakarta: PP Muhammadiyah, 2015), 10-11. 
${ }^{48}$ Tim Penyusun PP Muhammadiyah, "Indonesia Berkemajuan: Rekonstruksi Kehidupan Berbangsa Yang Bermakna” (Yogyakarta: PP Muhammadiyah, 2015), p. 11-12.

${ }^{49}$ Tim Penyusun PP Muhammadiyah, "Indonesia Berkemajuan," 12.

${ }^{50}$ Tim Penyusun PP Muhammadiyah, "Indonesia Berkemajuan," 12.

${ }^{51}$ Tim Penyusun PP Muhammadiyah, "Indonesia Berkemajuan," 12..

${ }^{52}$ PP Muhammadiyah, "Negara Pancasila Sebagai Darul Ahdi Wasy Syahadah" (Yogyakarta: PP Muhammadiyah, 2015), 15-16. 